\title{
Menurunkan Kejadian Demam Berdarah Dengue dengan Pengetahuan dan Pelaksanaan Pencegahan
}

\section{Reducing the incidence of dengue fever with knowledge and prevention}

\author{
Rita Sari ${ }^{1, \bowtie}$, Anifatmawati Anifatmawati ${ }^{1}$ \\ ${ }^{1}$ STIKes, Muhammadiyah Pringsewu Lampung, Indonesia \\ $\bowtie$ Corresponding author: ritasari74@gmail.com
}

\section{Kata kunci:}

Pengetahuan DBD, pelaksanaan pencegahan, DBD.

Keyword:

Knowledge of $\mathrm{DHF}$, preventionimplementation, DHF.

\begin{abstract}
Abstrak
Latar belakang: Penyakit DBD masih menjadi masalah masyarakat yang bersifat endemik. Pencegahan dan pemberantasan penyakit DBD sampai saat belum mampu membebaskan masyarakat dari penyakit DBD. Tujuan: Penelitian ini bertujuan mengetahui hubungan pengetahuan dan pelaksanaan pencegahan DBD dengan kejadian DBD di Pringsewu Selatan di wilayah kerja puskesmas Pringsewu tahun 2015. Metode: Subjek penelitian ini adalah masyarakat Pringsewu Selatan sebanyak 80 responden Jenis penelitian ini adalah survey analitik, menggunakan metode penelitian kuantitatif dengan pendekatan cross sectional. Tekhnik pengambilan sampel dalam peneltian ini menggunakan tekhnik systematic sampling. Analisis bivariat dengan menggunakan uji chisquare dengan tingkat kepercayaan $95 \%$. Hasil: Hasil apenelitian menunjukkan ada hubungan tingkat pengetahuan dengan kejadian DBD dengan $\mathrm{p}$ value 0,012 ( $\mathrm{p}$ value $<0,05$ ) dan ada hubungan pelaksanaan pencegahan dengan kejadian DBD dengan $\mathrm{p}$ value 0,002 (p value< 0,05). Simpulan: Kejadian DBD berhubungan dengan faktor tingkat pengetahuan yang kurang dan pelaksanaan pencegahan timbulnya endemik DBD.
\end{abstract}

\begin{abstract}
Background: DHF is still an endemic problem for people. Prevention and eradication of DHF until now has not been able to free the community from DHF. Objective: This study aims to determine the relationship of knowledge and implementation of DHF prevention with the incidence of DHF in South Pringsewu in the working area of Pringsewu Public Health Center in 2015. Methods: The subjects of this study are the South Pringsewu community of 80 respondents. This research type is analytic survey, using quantitative research methods with cross sectional approach. The sampling technique in this research uses systematic sampling technique. Bivariate analysis using chi-square test with a confidence level of 95\%. Results: The results of the study showed that there was a relationship between the level of knowledge and the incidence of DHF with $p$ value 0.012 ( $p$ value <0.05) and there was a correlation between the implementation of prevention with DHF incidence with $p$ value 0.002 ( $p$ value $<0.05)$. Conclusion: The incidence of DHF is related to the factor of lack of knowledge and the implementation of prevention of DHF endemic emergence.
\end{abstract}




\section{Pendahuluan}

Provinsi Lampung merupakan daerah yang memiliki iklim tropis. Kasus demam berdarah dengue (DBD) di Provinsi Lampung sangat banyak pada musim perubahan cuaca sekarang ini.Di Provinsi Lampung kasusDBD pada tahun 2014mencapai 656 kasus dan 7 orang meninggal, yaitu di Tanggamus sebanyak 1 orang meninggal, Bandar lampung 3 orang meninggal, Pesawaran 1 orang meninggal, Pringsewu 3 orang meninggal, Metro 1 orang meninggal dan Lampung Utara 1 orang meninggal, dari 656 kasus tersebut Metro 134 kasus (20,42\%), Bandar Lampung 96 kasus (14,63\%), Tanggamus 51 kasus (7,77\%), Pesawaran 33 kasus (5,03\%), Lampung Selatan 92 (14,02\%), dan Pringsewu 349 (53,20\%) kasus (Dinkes Pringsewu, 2014).

Kejadian DBD di Kabupaten Pringsewu, berdasarkan catatan Dinas Kesehatan Pringsewu pada tahun 2014, Kecamatan Pagelaran dengan kasus DBD mencapai 25 kasus (7,16 \%), Kecamatan Bumiratu mencapai 24 kasus (6,87\%), Kecamatan Pringsewu mencapai 91 kasus (26,07\%) dengan 2 orang meninggal, Kecamatan Ambarawa mencapai 46 kasus (13,18\%), Kecamatan Sukoharjo mencapai 44 kasus (12,60\%), Kecamatan Banyumas mencapai 2 kasus (0,57\%), Kecamatan Adiluwih mencapai 7 kasus (2,00\%) dengan 1 orang meninggal, Kecamatan Gadingrejo mencapai 47 kasus (13,46\%), Kecamatan Wates mencapai 24 kasus (6,87\%), dan Kecamatan Pardasuka mencapai 39 kasus (11,17\%). Dengan demikian Kecamatan Pringsewu menduduki urutan pertama tertinggi terjadi kasus DBD (Dinkes Pringsewu, 2014).

Berdasarkan studi pendahuluan yang dilakukan di Pringsewu Selatan pada 30 responden terdapat 22 $(73,33 \%)$ responden tidak mengetahui akan penyakit DBD dan pelaksanaan pencegahannya, Pringsewu Selatan merupakan Wilayah Kerja Puskesmas Pringsewu dengan jumlah penderita DBD tertinggi dari 15 desa di Wilayah Kerja Puskesmas Pringsewu. Sedangkan sampai saat ini penyakit DBD masih menjadi masalah masyarakat dimana pencegahan dan pemberantasan penyakit DBD sampai saat ini di prioritaskan pemberantasan nyamuk aedes aegepty dan larvanya. Keberhasilan pencegahan DBD membutuhkan partisipasi masyarakat. Pengetahuan tentang penyakit DBD serta pencegahannya menjadi hal penting diketahui masyarakat (Soegoeng, 2008).

Hubungan pengetahuan dengan penyakit DBD, pengetahuan yang rendah justru dapat menjadi faktor utama dari kejadian DBD, namun dalam kejadian kasus DBD lebih banyak berpengetahuan rendah daripada pengetahuan baik. Penelitian Soegoeng (2008) tentang hubungan perubahan iklim, kelembapan tempat tinggal, kepadatan larva aedes aegepty, prilaku bersih dengan kejadian DBD didapatkan adanya hubungan perubahan iklim, kelembapan tempat tinggal, kepadatan larva aedes aegepty, prilaku bersih dan sehat yang belum terwujud serta lingkungan hidup yang belum memadai dengan kejadian luar biasa penyakit DBD (Aboesina, 2012). Penelitian ini bertujuan untuk mengetahui hubungan Pengetahuan dan Pelaksanaan Pencegahan DBD dengan kejadian DBD di Pringsewu Selatan di Wilayah Kerja Puskesmas Pringsewu tahun 2015.

\section{Metode}

Penelitian ini menggunakan survei analitik yaitu penelitian yang menilai hubungan antar variabelvariabel yang diteliti yang dilakukan dengan metode survey.Rancangan penelitian menggunakan pendekatan cross sectional yaitu penelitian yang mempelajari dinamika korelasi antara faktor risiko dan efek dimana kedua faktor tersebut diukur atau dikaji dalam satu waktu atau simultan (Notoatmodjo, S. 2010). 
Penelitian ini mempunyai dua variabel, yaitu variabel dependen kejadian DBD dan variable independen pengetahuan dan pelaksanaan pencegahan DBD. Populasi pada penelitian ini adalah masyarakat di lingkungan VI Pringsewu Selatan di Wilayah Kerja Puskesmas Pringsewu tahun 2015. Populasi yang digunakan adalah seluruh masyarakat yang berjumlah 434 kepala keluarga. Sampel yang dipilih adalah sebanyak 80 responden. Tekhnik pengambilan sampel dalam peneltian ini menggunakan tehnik systematic sampling. Analisis bivariat dengan menggunakan uji chi-square dengan tingkat kepercayaan $95 \%$.

\section{Hasil}

Hasil analisis univariat dan bivariat tentang pengetahuan dan sikap tentang DBD dengan kejadian DBD dapat dilihat pada tabel 1. Berdasarkan tabel 1 dapat diketahui bahwa sebagian besar responden dengan pengetahuan baik yaitu 46 responden (57,5\%), sedangkan tentang pelaksanaan pencegahan menunjukan bahwa responden dengan perilaku pencegahan baik sebanyak 42 responden (52,5\%). Hasil analisis untuk kejadian DBD di Pringsewu Selatan terdapat 33 responden $(41,3 \%)$ dengan DBD.

Tabel 1.

Distribusi Pengetahuan, Pelaksanaan dalam Pencegahan DBD dan Kejadian DBD di Pringsewu Selatan Lampung Tahun 2015

\begin{tabular}{lcc}
\hline \multicolumn{1}{c}{ Varibel } & Frekuensi (n) & Persentase (\%) \\
\hline Pengetahuan & 46 & 57,5 \\
Baik & 34 & 42,5 \\
Kurang & & \\
Pelaksanaan Pencegahan & 42 & 52,5 \\
Baik & 38 & 47,5 \\
Kurang & & \\
Kejadian DBD & 33 & 41,2 \\
Kasus DBD & 47 & 58,8 \\
Bukan DBD & & \\
\hline
\end{tabular}

\section{Analisis bivariat}

Berdasarkan tabel 2 untuk variabel pengetahuan dapat diketahui bahwa dari 46 responden dengan pengetahuan baik terdapat 13 orang $(28,3 \%)$ dengan kasus DBD, sedangkan dari 34 responden yang pengetahuannya kurang baik ada 20 responden (58,8\%)dengan DBD. Hasil uji statistik dengan Chi Square diperoleh $p$-value $=0,017$ yang berarti $\mathrm{p}<\alpha=0,05$ (Ho ditolak), maka dapat disimpulkan bahwa ada hubungan yang signifikan antara pengetahuan dengan kejadian DBD di Pringsewu Selatan di Wilayah Kerja Puskesmas Pringsewu Tahun 2015.

Hasil analisis bivariat untuk pelaksanaan pencegahan dapat dijelaskan bahwadari 42responden dengan pelaksanaan pencegahan baik terdapat 10 orang $(23,8 \%)$ dengan kasus DBD, sedangkan dari 38 responden yang pengetahuannya kurang baik ada 23 responden $(60,5 \%)$ dengan DBD. Hasil uji statistik dengan Chi Square diperoleh $p$-value $=0,003$ yang berarti $\mathrm{p}<\alpha=0,05$ (Ho ditolak), maka dapat disimpulkan bahwa ada hubungan yang signifikan antara pelaksanaan pencegahan dengan kejadian DBD di Pringsewu Selatan di Wilayah Kerja Puskesmas Pringsewu Tahun 2015. 
Tabel 2.

Distribusi Pengetahuan dan Pelaksanaan dalam Pencegahan DBD dengan Kejadian DBD di Pringsewu Selatan Tahun 2015

\begin{tabular}{|c|c|c|c|c|c|c|c|}
\hline \multirow{3}{*}{ Variabel } & \multicolumn{4}{|c|}{ Kejadian DBD } & \multirow{2}{*}{\multicolumn{2}{|c|}{ Total }} & \multirow{3}{*}{ P-valuc } \\
\hline & \multicolumn{2}{|c|}{ DBD } & \multicolumn{2}{|c|}{ Bukan DBD } & & & \\
\hline & $\mathbf{n}$ & $\%$ & $\mathbf{n}$ & $\%$ & n & $\%$ & \\
\hline \multicolumn{8}{|l|}{ Pengetahuan } \\
\hline a.Baik & 13 & 28,3 & 33 & 71,7 & 46 & 100 & 0,017 \\
\hline b.Kurang baik & 20 & 58,8 & 14 & 41,2 & 34 & 100 & \\
\hline \multicolumn{8}{|l|}{ Pelaksanaan } \\
\hline \multicolumn{8}{|l|}{ Pencegahan } \\
\hline a.Baik & 10 & 23,8 & 32 & 76,2 & 42 & 100 & 0,003 \\
\hline b.Kurang baik & 23 & 60,5 & 15 & 39,5 & 38 & 100 & \\
\hline
\end{tabular}

\section{Pembahasan}

\section{Pengetahuan responden tentang DBD}

Hasil penelitian ini didapatkan pengetahuan tentang DBD didapat paling banyak responden dengan pengetahuan baik berjumlah 46 responden (57,5\%), sedangkan responden dengan pengetahuan kurang adalah sebanyak 34 responden (42,5\%).Hasil penelitian ini sejalan dengan hasil penelitian sebelumnya yang dilakukan oleh Juwita tentang gambaran pengetahuan KK tentang DBD di Wilayah Kerja Puskesmas Kasihan II Bantul Joggakarta. Hasil penelitian didapat bahwa mayoritas pengetahuan masyarakat tentang penyakit DBD termasuk dalam kategori pengetahuan buruk (76,5\%) (Juwita, 2008). Hasil penelitian ini juga sejalan dengan penelitian yang dilakukan Sigalingging tentang gambaran pengetahuan keluarga penderita DBD di Puskesmas Simpang Limun Medan Tahun 2011. Hasil penelitian didapat mayoritas pengetahuan masyarakat tentang penyakit DBD termasuk dalam kategori pengetahuan baik (73,33\%) (Juwita, 2008). Hasil penelitian lain yang sejalan dengan hasil penelitian ini adalah penelitian yang dilakukan oleh Ipa tentang gambaran pengetahuan, sikap dan tindakan masyarakat serta hubungannya dengan kejadian Demam Berdarah Dengue di Kecamatan Pengandaran Kabupaten Ciamis Tahun 2007. Hasil penelitian didapatkan pengetahuan tentang DBD 63,59\% adalah baik (Ipa, 2007).

Tujuan pengetahuan tentang DBD adalah keluarga/masyarakat dapat mengetahui tentang pencegahan DBD. Keluarga dapat menjaga kebersihan rumah serta lingkungan dari jentik-jentik nyamuk di sekitar pekarangan tempat tinggal mereka. Maka dari itu tim kesehatan agar lebih meninggatkan penyuluhan kesehatan tentang pencegahan DBD kepada masyarakat atau keluarga. Pengetahuan sangat penting sebagai dasar perilaku manusia bidang kesehatan. Masyarakat akan melakukan perilaku sehat jika masyarakat mengetahui apa manfaat dari perilaku tersebut. Penyuluhan yang lebih baik akan menambah pengetahuan masyarakat akan perilaku hidup bersih dan sehat.

\section{Pelaksanaan pencegahan DBD}

Hasil penelitian ini menunjukkan bahwa distribusi responden dengan berperilaku pencegahan baik yaitu 42 responden $(52,5 \%)$, sedangkan responden yang berperilaku pencegahan kurang baik adalah sebanyak 38responden (47,5\%). Hasil penelitian ini sejalan dengan penelitian oleh Ipa tentang gambaran pengetahuan, sikap dan tindakan masyarakat serta hubungannya dengan kejadian Demam Berdarah Dengue di Kecamatan Pengandaran Kabupaten Ciamis Tahun 2007. Hasil penelitian didapat perilaku responden baik (70\%) (Ipa, 2007). 
Sejalan dengan teori yang dikemukan oleh Mc. Dougall yang mengatakan bahwa perilaku merupakan aksi dari individu terhadap reaksi dari hubungan dengan lingkungannya, dengan kata lain perilaku terjadi bila ada sesuatu yang diperlukan untuk menimbulkan reaksi, sesuatu tersebut dinamakan rangsangan (Mc. Dougall, 2007). Berdasarkan hasil penelitian yang dihubungkan dengan penelitian terkait sebelumnya serta teori yang berhubungan dengan penelitian ini maka penulis berpendapat bahwa perilaku kesehatan harus ditanamkan pada individu, keluarga dan masyarakat.

\section{Kejadian DBD}

Hasil penelitian ini didapatkan distribusi responden dengan kasus DBD yaitu33 responden $(41,3 \%)$, sedangkan responden dengan kasus bukan DBD adalah sebanyak 47responden (58,8\%).Hasil penelitian di atas sejalan dengan teori yang disampaikan Saferi \& Marisa, bahwa kejadian DBD dapat timbul akibat pengaruh faktor Agent (nyamuk), host (manusia) seperti kepadatan pemukiman penduduk, pekerjaan dan penghasilan, pengetahuan, sikap dan perilaku, dan yang ketiga lingkungan ( Saferi, Andara \& Marisa, Yesi .2014).Hasil penelitian ini juga sejalan dengan teori yang dikemukan oleh Indrawan dalam Rampengan (2008), yang menyatakan bahwa salah satu infeksi yang serius yang dikenal pula dengan sebutan DBD.Serta sejalan juga dengan teori Rampengan demam berdarah dengue merupakan penyakit infeksi yang menimbulkan masalah kesehatan di negara yang berkembang, khususnya Indonesia, hal ini disebabkan oleh tingginya morbiditas dan mortalitas sejalan juga dengan teori WHO bahwa demam berdarah dengue adalah oleh virus dengue dan ditularkan melalui gigitan nyamuk aedes aegepty.

Demam berdarah dengue merupakan gambaran klinis dari Df sering tergantung pada usia pasien. Bayi dan anak kecil dapat mengalami penyakit demam un differentiated, sering dengan ruam mokulopapular. Anak yang lebih besar dan orang dewasa dapat mengalami demam tinggi mendadak, sakit kepala berat, nyeri di belakang mata, nyeri otot, tulang atau sendi, mual dan muntah (WHO, 2009)

Berdasarkan hasil di atas, maka dapat disimpulkan bahwa tingginya kejadian DBD di Pringsewu Selatan dimungkinkan karena kondisi geografis, pengetahuan; dan perilaku warga yang tinggal di desa tersebut. Secara geografis sebagian besar wilayah merupakan daerah yang masih banyak tanaman dan pohon yang menyebabkan lembab, serta selokan yang tidak lancar sehingga pada musim hujan menyebabkan genangan air. Tempurung kelapa, kaleng, tempat bekas yang bisa menampung air, pada musim hujan dapat menampung air dan menjadi tempat perindukan nyamuk DBD.

\section{Hubungan antara pengetahuan dengan kejadian DBD}

Hasil penelitian menunjukkan bahwa ada hubungan yang bermakna antara pengetahuan dengan kejadian DBD. Hal ini berarti bahwa pengetahuan yang kurang tentang DBD berisiko menyebabkan sakit DBD, karena pengetahuan merupakan domain penting untuk mempengaruhi tindakan seseorang dalam mencegah penyakit DBD. Hasil penelitian ini sejalan dengan hasil penelitian sebelumnya yang dilakukan oleh Indrawan menunjukan adanya hubungan antara pengetahuan dengan perilaku 3M di Kelurahan Landasan Ulin bara (Indrawan, 2007) dan penelitian yang dilakukan oleh Mulia tentang hubungan pengetahuan tentang DBD dengan perilaku PSN di Desa Jenggala Kudus (Mulia, 2008). Hasil penelitian lain adalah penelitian yang dilakukan oleh Santoso tentang hubungan pengetahuan, sikap dan perilaku masyarakat terhadap Vektor DBD di Kota Palembang (Santoso, 2005). Begitu juga dengan penelitian yang dilakukan Nahumasury tentang hubungan pengetahuan, sikap dan tindakan pemberatasan sarang nyamuk aedes aegepty dengan keberadaan larva di Kota Makasar Tahun 2013 (Nahumasury, 2013). 
Pengetahuan merupakan hal tahu atau pemahaman akan sesuatu yang bersifat spontan tanpa mengetahui seluk beluknya serta mendalam. Pada hakikatnya, segala apa yang kita ketahui tentang sesuatu objek tertentu (Ilyas, 2013).Berdasarkan hasil di atas maka dapat disimpulkan bahwa dengan adanya hubungan pengetahuan dengan kejadian DBD, hendaknya petugas kesehatan lebih sering melakukan penyuluhan tentang DBD. Pengetahuan keluarga yang kurang tentang tanda, gejala, cara penularan dan pencegahan DBD mempunyai resiko menderita DBD.

Dengan demikian, upaya peningkatan pengetahuan perlu perhatian khusus agar keluarga dapat berperan aktif dalam upaya penanggulangan DBD. Cara untuk menambah pengetahuan keluarga tersebut misalnya dengan memberikan informasi-informasi tentang DBD melalui penyuluhan baik secaraa langsung saat posyandu maupun menggunakan media, elektronik, poster DBD dan lain-lain.Diharapkan pengetahuan tentang kejadian penyakit DBD dapat menjadi sumber inspirasi seseorang untuk bersikap dan berperilaku lebih baik. Pengetahuan yang dimiliki keluarga diharapkan dapat memodifikasi kondisi lingkungan sesuai dengan kemampuan yang berbasis lingkungan dapat dicegah, penderita dapat segera mendapat pertolongan dengan benar dan tidak ada lagi korban meninggal akibat keterlambatan penanganan yang diawali oleh pengetahuan tentang kesehatan yang dimiliki keluarga.

\section{Hubungan antara pelaksanaan pencegahan dengan kejadian DBD}

Hasil analisis bivariat menunjukan bahwa ada hubungan yang bermakna antara perilaku dengan kejadian DBD. Adanya hubungan antara kedua variabel ditunjukan dari hasil perhitungan nilai korelasi chi square dengan tingkat kesalahan $5 \%$ diperoleh $p$ value $=0,002$. Hasil penelitian ini sejalan dengan hasil penelitian yang dilakukan oleh Mahardika tentang Hubungan antara Perilaku Kesehatan dengan Kejadian DBD, diketahui bahwa adanya hubungan yang signifikan antara perilaku terhadap kejadian DBD ( $\mathrm{p}$ value $=0,002)$ (Mahardika, 2009). Sejalan dengan hasil penelitian yang dilakukan oleh Santoso bahwa hubungan pengetahuan, sikap dan perilaku masyarakat terhadap Vektor DBD di Kota Palembang. adanya hubungan yang signifikan antara perilaku responden kaitanya dengan penyakit DBD dengan hasil ( $\mathrm{p}$ value $=0,005)$ dengan OR 1,62 (Santoso, 2005). Hasilini juga sejalan dengan hasil penelitian Nahdah, di Kota Palu mengenai hubungan perilaku $3 \mathrm{M}$ plus dengan keberadaan Larva aedes aegepty di Kelurahan Birobuli Selatan Kota Palu Sulawesi Tengah. Bahwa ada hubungan yang signifikan antara perilaku dengan keberadaan Larva aedes aegepty dengan ( $\mathrm{p}$ value $=0,035$ ) dimana $\mathrm{p}$ value $<0,05$ (Mahardika, 2009). Sejalan dengan penelitian yang dilakukan oleh Widjaja, di Kota Palu. Dari hasil statistik menggunakan Chi square diperoleh nilai ( $\mathrm{p}$ value $=0,002$ ) yang menunjukan ada hubungan antara perilaku dengan keberadaan larva di Daerah endemis DBD di Kota Palu (Widjaja, 2007).

Perilaku kesehatan dipengaruhi oleh tiga faktor yaitu faktor prodisposisi (predisposing factor) yang terwujud dalam pengetahuan, sikap, kepercayaan, keyakinan dan nilai-nilai. Faktor kedua yaitu pendukung (enabling factor) yang terwujud dalam lingkungan fisik, fasilitas kesehatan dan keterjangkauan fasilitas-fasilitas tersebut. Faktor ketiga yaitu faktor pendorong (reinforcing factor), berupa contoh sikap dan perilaku hidup sehat dari tokoh masyarakat, tokoh agama, kader-kader dan petugas kesahatan dan termasuk di dalamnya yaitu perilaku dari kepala keluarga (Green, 2005). Berdasarkan hasil di atas maka dapat disimpulkan bahwa resiko terjangkit penyakit DBD akan lebih besar bila tidak diselaraskan dengan perilaku baik oleh keluarga dalam mencegah dan mengatasi masalah kesehatan. Perilaku merupakan suatu respon terhadap rangsangan atau stimulus dari luar. Adanya ancaman kesehatan harus mendapaat respon yang baik dari keluarga untuk melakukan kegiatan-kegiatan guna menghindari ancaman/masalah kesehatan tersebut. Adanya perilaku contoh (Role Model) dari tokoh 
masyarakat, tokoh agama, kader-kader serta tenaga kesehatan lingkungan sehingga keluarga tersebut dapat berperilaku lebih bersahabat dengan lingkungan tempat tinggalnya.

\section{Simpulan dan saran}

Faktor pengetahuan kurang dan pelaksanaan pencegahan yang tidak baik meningkatkan kejadian DBD. Hendaknya petugas kesehatan lebih sering melakukan penyuluhan pencegahan DBD dan akibatnya. Perlunya perilaku contoh (role model) dari tokoh masyarakat, tokoh agama, kader-kader dan tenaga kesehatan lingkungan, sehingga keluarga di lingkungan tersebut dapat berperilaku lebih sehat dalam mencegah terjadinya endemik DBD setiap tahun.

\section{Referensi}

Aboesina. (2012)., Hubungan pengetahuan ibu tentang penyakit DBD. Skripsi. Universitas Diponegoro.

Dinkes Pringsewu. (2014). Profil kesehatan kabupaten Pringsewu. Pringsewu: Dinkes Pringsewu

Green, L. (2005). Health program planing, Mc Graw Hill, New York.

Ilyas. (2013). Pengertian pengetahuan.Digilib Unila.Universitas Lampung

Indrawan. (2007). Hubungan antara pengetahuan dengan perilaku 3M di kelurahan landasan ulin bara. Skripsi. Universitas Padjajaran

Ipa. (2007). Gambaran pengetahuan, sikap, dan tindakan masyarakat. E-journal.Litbang.Depkes.

Juwita. (2008). Gambaran pengetahuan KK tentang DBD di wilayah kerja puskesmas kasihan II Bantul Yogyakarta. Skripsi. Universitas Muhammadiyah Yogyakarta

Mahardika. (2009). Hubungan antara perilaku kesehatan dengan kejadian DBD. Skripsi. Universitas Negeri Semarang

Dougall, M.C. (2007). Behavior health comunity, Alih Bahasa, Ahmad Yuda. Jakarta: Rineka Cipta.

Mulia. (2008). Hubungan antara pengetahuan tentang DBD dengan perilaku PSN di desa Jenggala Kudus. Skripsi. Universitas Negeri Semarang.

Nahdah. (2013). Hubungan perilaku 3M plus dengan keberadaan larva aedes aegepty di kelurahan biro buli selatan kota palu sulawesi tengah. Skripsi. Universitas Hasanudin

Nahumasury. (2013). Hubungan pengetahuan, sikap, dan tindakan pemberantasan sarang nyamuk aedes aegepty dengan keberadaan larva di kota makasar. Skripsi. Universitas Hasanudin

Notoatmodjo, S. (2010). Metodologi penelitian kesehatan, Edisi Revisi Jakarta: Rineka Cipta.

Rampengan. (2008). Penyakit infeksi trofik pada anak, Jakarta: EGC.

Saferi, A., \& Marisa, Y. (2014). Keperawatan medikal bedah. Jogjakarta: Nuha Medika.

Santoso. (2005). Hubungan pengetahuan, sikap, dan perilaku masyarakat terhadap Vektor DBD di Kota Palembang. journal. Litbang: Depkes

Sigalingging. (2011). Gambaran pengetahuan keluarga penderita DBD di puskesmas simpang limun Medan. Skripsi. Universitas Sumatra Utara

Soegoeng. (2008). Demam berdarah dengue edisi kedua. Jakarta: Airlangga University Press

Widjaja. (2007). Hubungan antara perilaku dengan keberadaan larva di daerah endemis DBD di Kota Palu. Skripsi. Universitas Hasanudin 
Menurunkan Kejadian Demam Berdarah Dengue dengan Pengetahuan dan Pelaksanaan Pencegahan Rita Sari, Anifatmawati Anifatmawati

Jurnal Kesehatan Metro Sai Wawai. 10 (2) 2017. E-ISSN2657-1390. P-ISSN19779-469X

World Health Organization. (2009). Pencegahan dan penanggulangan penyakit demam dengue dan demam berdarah dengue. Petunjuk lengkap. Terjemahan oleh Suroso, T, dkk dari Prevention Control of Dengue and Dengue Haemorrhagic Fever. World Health Organization dan Departemen Kesehatan. 